\title{
Primary Production and Carrying Capacity of Former Salt Ponds After Reconnection to San Francisco Bay
}

\author{
Julien Thébault ${ }^{1,2}$, Tara S. Schraga ${ }^{1}$, James E. Cloern ${ }^{1}$, and Eric G. Dunlavey ${ }^{3}$ \\ ${ }^{1}$ United States Geological Survey \\ 345 Middlefield Rd., MS 496 \\ Menlo Park, California, USA 94025 \\ ${ }^{2}$ IUEM-UBO, UMR CNRS 6539 \\ Place Nicolas Copernic \\ 29280 Plouzané, France \\ ${ }^{3}$ City of San Jose, Environmental Services Department \\ 700 Los Esteros Rd. \\ San Jose, California, USA 95134
}

\begin{abstract}
Over 6110 ha of the commercial production salt ponds surrounding South San Francisco Bay, $\mathrm{CA}$, have been decommissioned and reconnected to the bay, most as part of the largest wetlands restoration program in the western United States. These open water ponds are critical habitat for millions of birds annually and restoration program managers must determine the appropriate balance between retention of ponds versus re-conversion to tidal salt marsh, knowing that both are essential ecosystems for endangered bird species. Our study describes the ecological value of the new open water pond ecosystems as feeding habitats for birds. We used the oxygen rate of change method to determine ecosystem metabolic parameters from high resolution time-series of dissolved oxygen concentration. Areal gross primary production $\left(8.17 \mathrm{~g} \mathrm{O}_{2} \mathrm{~m}^{-2} \mathrm{~d}^{-1}\right)$ was roughly double the world's most productive estuaries. High rates of phytoplankton photosynthesis were balanced by equally high rates of community respiration $\left(8.25 \mathrm{~g} \mathrm{O}_{2} \mathrm{~m}^{-2} \mathrm{~d}^{-1}\right)$. Metabolic equilibrium was delicately poised: sharp irradiance and temperature shifts triggered short term photosynthesis reduction resulting in oxygen depletion. We converted net primary production (NPP) into potential carrying capacity of the forage biota that support targeted pond waterbirds. NPP was processed through both a pelagic food web, resulting in forage biota for piscivorous birds and a benthic food web, resulting in forage biota for shorebirds and diving benthivores. Both food webs included efficient algal-based and inefficient detrital trophic pathways. The result of all primary production being routed through simple food webs was high potential forage production and energy supply to waterbirds, equivalent to 11-163 million planktivorous fish or 19-78 billion small estuarine clams within the 330-ha pond between May and October. Food quantity does not necessarily equal quality and these systems have the potential to produce toxic or inedible algae. Our study provides the first measurement of primary production in the open water ponds of San Francisco Bay and presents a novel approach for transforming primary production into forage production as a metric of an ecosystem's energetic carrying capacity.
\end{abstract}

Key Words: birds, dissolved oxygen concentration, ecosystem restoration, food webs, forage biota, net ecosystem metabolism, phytoplankton 


\section{INTRODUCTION}

San Francisco Bay has been named the urbanized estuary (Conomos 1979) because of its geographic setting within the densely populated metropolitan area between San Francisco, Oakland, and Silicon Valley. Landscape transformations of the bay began immediately after California's population explosion was launched by the 1849 gold rush (Nichols et al. 1986), and included diking and conversion of native salt marsh around the South Bay (Figure 1) into shallow ponds managed for solar evaporation salt production. The commercial salt pond network grew to encompass approximately 10,500 ha of former tidal wetlands south of the San Mateo Bridge. The ponds are now of primary importance to migratory waterbirds, and also provide year round foraging habitat for a number of resident species. In all, at least 70 endangered, rare, and common bird species inhabit, breed, or feed on the ponds, and the annual bird use of ponds numbers in the millions (Warnock et al. 2002).

Beginning in 2004, a significant portion of the production salt ponds (6110 ha) were decommissioned and opened to exchange with water from the bay or adjacent sloughs. The decommissioned ponds are presently managed as non-tidal or minimally tidal open water systems, most as part of the South Bay Salt Pond Restoration Project (SBSPRP; http://www.southbayrestoration.org). This is the largest program of wetland restoration in the western United States, conceived to rebuild wetland habitats to sustain endangered species of plants, birds, and mammals. Program managers face a critical decision about how to adaptively manage these ponds to meet multiple ecological goals, namely determine the appropriate balance between newly restored salt marshes that are home to endemic birds such as the endangered California clapper rail (Rallus longirostris obsoletus) and Alameda song sparrow (Melospiza melodia pusillula) versus retention of salt ponds that over the past century have increased populations of permanent and migratory waterbirds such as the American white pelican (Pelecanus erythrorhynchos) and the endangered western snowy plover (Charadrius alexandrinus). Eliminating artificial salt pond habitats without concomitantly restoring natural salt ponds and tidal salt marshes with pans could reduce or even extirpate some of these species from the bay (Takekawa et al. 2006). Moreover, questions remain about which open ponds to maintain and which ones to restore.

An important criterion to inform the decision-making process is the ecological value of pond and salt marsh habitats (Lopez et al. 2006). Fundamental ecological parameters such as primary production have not been measured in these high-biomass shallow habitats, a first step in quantifying the pond's ecological functioning and contribution to the greater system. In this paper we explore quantity and quality of local production that sustains food webs in one South San Francisco Bay pond. We calculate primary production and ecosystem metabolism from high resolution dissolved oxygen measurements using the oxygen curve method first described by Odum (1956) and subsequently applied in numerous studies (McKenna 2003, Caffrey 2004, Russell and Montagna 2007). Using a novel approach, we convert the primary production via simple food webs into estimates of potential carrying capacity of forage organisms that support the target bird species. Carrying capacity is expressed in units that are meaningful for restoration project managers, providing tangible ecological metrics for valuating different habitat types and understanding the outcomes of adaptive management decisions. 


\section{METHODS}

\section{Site Description}

Pond A18 ( $\left.37^{\circ} 27^{\prime} \mathrm{N}, 121^{\circ} 57^{\prime} \mathrm{W}\right)$ is one of the largest (330 ha) decommissioned salt ponds in South San Francisco Bay. The pond's levees are bounded by three tidal channels connected to San Francisco Bay: Artesian Slough to the west, Coyote Creek to the north, and Coyote Creek Bypass Channel to the northeast (Figure 1). Artesian Slough receives 386 million liters of treated wastewater daily from the San Jose/Santa Clara Water Pollution Control Plant (City of San Jose 2007a). Wastewater inputs contribute to the very high nutrient concentrations in lower South San Francisco Bay and its ponds. For example, analyses across 25 ponds in May and June of 2003 and 2006 measured concentrations of dissolved inorganic nitrogen (DIN) and soluble reactive phosphorus (SRP) that always exceeded levels that limit phytoplankton growth (mean DIN $=84 \mu \mathrm{M}$ with $91 \%$ as $\mathrm{NH}_{4}$; mean $\mathrm{SRP}=2.6 \mu \mathrm{M} ; \mathrm{A}$. K. Miles, USGS, pers. comm.).

The City of San Jose purchased Pond A18 in 2005 and manages the pond's connectivity through one inlet and one outlet constructed as $1.22-\mathrm{m}$ diameter culverts having one-way tide gates. The inlet is located in the northwest corner (Figure 1) where mixtures of water from Artesian Slough and South San Francisco Bay enter the pond. The outlet is in the southwestern corner (Figure 1) where pond water discharges into Artesian Slough. Water exchange with the pond is unidirectional: intake in the north, discharge in the south. Tides are predominantly semidiurnal, thus water enters and exits the pond twice daily when tide heights are below the outlet and above the intake. Pond A18 functions as a nearly closed system rather than an open flow-through system, as evidenced by hydraulic residence time estimated between 15 and 50 days (City of San Jose, Environmental Services Department, unpubl.).

Bathymetry of Pond A18 is characteristic of other South Bay salt ponds, with an expansive shallow (mean depth $=0.7 \mathrm{~m})$ area rimmed by a narrow trench $(1.2-1.8 \mathrm{~m}$ deep) created by excavation for levee construction. All of these shallow open water ponds are bounded by levees that separate them from the surrounding bay and brackish sloughs. Pond A18 is used as foraging and roosting habitat by the same communities of birds observed in other ponds having comparable salinity range (Takekawa et al. 2006). It is an example of an isolated high salinity pond (salinity before $2005=110$ ) that has been transformed by breaching its bounding levee, and as such it is a representative system for understanding ecological functions of shallow ponds with newly established tidal connectivity to San Francisco Bay.

\section{Water Quality Measurements in Pond A18}

Conductivity, temperature, and dissolved oxygen (DO) were measured at 15 minute intervals from May 1 to October 31, 2006, using YSI model 6600 datasondes deployed inside Pond A18 at the pond discharge location (City of San Jose 2007b). DO was measured with YSI rapid-pulse probes (membrane technology) from May to August, and YSI Reliable Optical DO probes (optical technology) from August through October. Simultaneous measurements from the two probes agreed within 1\% in side-by-side comparisons. Salinity, reported using the practical salinity scale, was determined automatically from sonde conductivity and temperature readings according to algorithms in Clesceri et al. (1998). Conductivity calibrations were performed using standards of $10,000 \mu \mathrm{S} \mathrm{cm}^{-1}$ and $50,000 \mu \mathrm{S}$ $\mathrm{cm}^{-1}$. DO sensors were calibrated to percent saturation using $100 \%$ standards of air saturated water (bubbled for $12 \mathrm{~h}$ ) or water saturated air (moist, vented calibration cup). The sondes were retrieved and replaced with a newly calibrated instrument at the end of each week. Data were downloaded to a computer and post-deployment calibration verification was conducted in the laboratory. DO data were accepted if the post-deployment sensor readings were within $\pm 10 \%$ of the standard. Conductivity data 
were accepted for the week if the post-deployment sensor readings were within $\pm 5 \%$ of the standard. Weekly data that did not meet the calibration confidence limits were discarded and these data gaps are reflected in our results.

Phytoplankton biomass was measured monthly as chlorophyll $a$ concentration $(\mathrm{Chl} a)$ in surface water at the discharge point. Samples were collected into $1 \mathrm{~L}$ bottles and stored in the dark on ice and transported to a laboratory within 4 hours for filtration and analysis (Clesceri et al. 1998).

Phytoplankton species composition was determined by microscopic analyses of samples collected on Aug 18, Sept 13, and Oct 19 at the discharge point inside of the pond and on Sept 13 and Oct 19 at the mouth of Artesian Slough.

\section{Weather Data}

We used weather data measured at Union City and provided by the California Irrigation Management Information System (CIMIS: http://wwwcimis.water.ca.gov/cimis/data.jsp). Wind speed $\left(\mathrm{m} \mathrm{s}^{-1}\right)$, water vapor pressure $(\mathrm{kPa})$, air temperature $\left({ }^{\circ} \mathrm{C}\right)$ and total solar radiation $\left(\mathrm{W} \mathrm{m}^{-2}\right)$ were recorded. We converted total solar radiation into photosynthetically active radiation (PAR, mol quanta $\mathrm{m}^{-2} \mathrm{~d}^{-1}$ ), assuming $1 \mathrm{~W} \mathrm{~m}^{-2}=0.4 \mathrm{~mol}$ quanta $\mathrm{m}^{-2} \mathrm{~d}^{-1}$ and PAR $=46 \%$ of total irradiance (Baker and Frouin 1987). The Union City CIMIS station did not provide sea level atmospheric pressure, therefore we used hourly data $(\mathrm{hPa})$ interpolated from measurements recorded every $3 \mathrm{~h}$ at San Francisco International Airport (NOAA, National Climatic Data Center). All data are reported as Pacific Standard Time (GMT-8).

\section{Primary Production, Respiration, and Ecosystem Metabolism}

We used the DO rate of change method first proposed by Odum (1956) to calculate daily gross primary production, ecosystem respiration, and net ecosystem metabolism from the continuous measurements of DO in Pond A18. Hourly rates of DO change were calculated from the 15 minute interval DO data (see Figure 2 for an example of diel DO variations). The rate of DO change is determined by rates of photosynthesis, respiration, accrual of other water sources, and atmospheric exchange. We assumed that accrual of DO from other water sources is negligible because of the pond's long residence time. Then, the measured rate of DO change each hour is described by the mass balance equation:

$$
\frac{\mathrm{d} C}{\mathrm{~d} t}=P-R+D \quad(\text { Eq. } 1)
$$

where $C$ is DO concentration in the pond $\left(\mathrm{mg} \mathrm{O}_{2} \mathrm{~L}^{-1}\right), t$ is time (h), $P$ is rate of photosynthesis, $R$ is the respiration rate, and $D$ is the rate of oxygen uptake by diffusion across the air-water interface $(P, R$, and $D$ units $\mathrm{mg} \mathrm{O}_{2} \mathrm{~L}^{-1} \mathrm{~h}^{-1}$ ).

Wind produces turbulence in stationary water bodies, facilitating gas exchange processes which increase with wind speed (Liss and Merlivat 1986). This relationship is represented as:

$$
D=k_{a}\left(C_{s}-C\right) \quad(\text { Eq. } 2)
$$

where $k_{a}$ is the volumetric reaeration coefficient $\left(\mathrm{h}^{-1}\right)$ and $C_{s}$ is the DO saturation concentration $\left(\mathrm{mg} \mathrm{O}_{2}\right.$ $\mathrm{L}^{-1}$ ). We calculated $k_{a}$ hourly using three different functions of wind speed (O'Connor 1983, Hartman and Hammond 1985, Ro and Hunt 2006) as an approach for estimating uncertainty in the rate of airwater oxygen exchange. Detailed methodology of these calculations is presented in Appendix A. The 
DO saturation concentration, which is dependent on water salinity and temperature, was calculated hourly using the algorithm of Benson and Krause (1984):

$$
\begin{aligned}
\ln C_{s}= & -135.29996+1.572288 \times 10^{5} \times T^{-1}-6.637149 \times 10^{7} \times T^{-2} \\
& +1.243678 \times 10^{10} \times T^{-3}-8.621061 \times 10^{11} \times T^{-4} \\
& -\left(0.020573-12.142 \times T^{-1}+2363.1 \times T^{-2}\right) \times S
\end{aligned}
$$

where $C_{S}$ is expressed in $\mu \mathrm{mol} \mathrm{O} \mathrm{kg}^{-1}, T$ is water temperature $(\mathrm{K})$, and $S$ is water salinity. The calculated $C_{s}$ was then converted to $\mathrm{mg} \mathrm{O}_{2} \mathrm{~L}^{-1}$ :

$$
C_{s}\left(\mathrm{mg} \mathrm{O}_{2} \mathrm{~L}^{-1}\right)=C_{s}\left(\mu \mathrm{mol} \mathrm{O} \mathrm{kg}^{-1}\right) \times \rho_{w} \times 31.9988 \times 10^{-6}
$$

where $\rho_{w}$ is the density of seawater $\left(\mathrm{kg} \mathrm{m}^{-3}\right)$ calculated hourly from atmospheric pressure, water temperature, and salinity according to the International Equation of State of Seawater IES-80

(UNESCO 1981).

Net ecosystem metabolism (NEM) is the difference between photosynthesis and respiration, which we computed (from rearrangement of Eq. 1) as:

$$
N E M=P-R=\frac{\mathrm{d} C}{\mathrm{~d} t}-D . \quad(\text { Eq. } 5)
$$

For each day we calculated daily NEM by summing hourly diffusion-corrected rates of DO change $(\mathrm{d} C / \mathrm{d} t-D)$ over $24 \mathrm{~h}$, starting and ending at sunrise. We next calculated hourly respiration rate $R$ as the average of nighttime (solar radiation $=0$ ) diffusion-corrected rates of DO change. By convention, respiration is expressed as a positive number, thus nighttime hourly diffusion-corrected rates of DO change were multiplied by -1 . We computed daily respiration as $24 \times R$, assuming respiration during the daytime is the same as at night. Hourly photosynthesis $P$ was calculated by subtracting $R$ from diffusion-corrected rates of DO change during the daylight period (solar radiation $>0$ ). We computed daily photosynthesis by summing $P$ from sunrise to sunset. We multiplied these volumetric rates by mean pond depth $(H=0.7 \mathrm{~m})$ to yield areal rates $\left(\mathrm{g} \mathrm{O}_{2} \mathrm{~m}^{-2} \mathrm{~d}^{-1}\right)$ of daily gross primary production (GPP $=[$ daily $P] \times H)$, ecosystem respiration $(\mathrm{ER}=[$ daily $R] \times H)$, and net ecosystem metabolism $(\mathrm{NEM}=$ GPP - ER).

These areal rates were also expressed in $\mathrm{C}$ units $\left(\mathrm{g} \mathrm{C} \mathrm{m}^{-2} \mathrm{~d}^{-1}\right)$. Based on nutrient surveys demonstrating that most of the DIN in South Bay ponds is in the recycled form of ammonium, we assumed a photosynthetic quotient of $1.1\left(\mathrm{O}_{2}: \mathrm{CO}_{2}\right.$ molar) characteristic of recycled production (Laws 1991). A respiratory quotient of 1 mole $\mathrm{O}_{2}$ consumed per mole of $\mathrm{C}$ respired was used.

\section{Estimation of Autotrophic and Heterotrophic Respiration}

Measures of phytoplankton biomass and photosynthesis allowed us to estimate rates of autotrophic respiration, based on the assumption that phytoplankton are the dominant autotrophs in Pond $\mathrm{A} 18$. We first calculated biomass-specific photosynthetic rates $P^{B}\left(\mathrm{mg} \mathrm{C}(\mathrm{mg} \mathrm{Chl} a \mathrm{~d})^{-1}\right)$ for each day when Chl $a$ was measured:

$$
P^{B}=1000 \times \frac{G P P}{H} \times \frac{1}{[C h l]} \quad(\text { Eq. } 6)
$$


where $[C h l]$ is the Chl $a$ concentration $\left(\mathrm{mg} \mathrm{Chl} a \mathrm{~m}^{-3}\right)$. We used 7-d mean values of GPP $\left(\mathrm{g} \mathrm{C} \mathrm{m}^{-2} \mathrm{~d}^{-1}\right)$, centered on Chl $a$ sampling dates, to smooth the variability of production caused by the daily fluctuations in weather. Next we calculated biomass-specific autotrophic respiration rate $r_{\text {auto }}\left(\mathrm{d}^{-1}\right)$ using Eq. 9 in Cloern et al. (1995):

$$
r_{\text {auto }}=0.15 \times P^{B} \times(C h l: C)+0.015 . \quad \text { (Eq. 7) }
$$

The phytoplankton Chl : C ratio (mg Chl $a\left(\mathrm{mg} \mathrm{C}^{-1}\right)$ was calculated using Eq. 15 in Cloern et al. (1995):

$$
C h l: C=0.003+0.0154 \times \mathrm{e}^{0.05 T} \times \mathrm{e}^{-0.059 \times(I /(k H)) \times\left(1-\mathrm{e}^{-k H}\right)} \times \frac{N}{K_{N}+N}
$$

where $T$ is $7-\mathrm{d}$ centered mean pond temperature $\left({ }^{\circ} \mathrm{C}\right), I$ is $7-\mathrm{d}$ centered mean daily PAR, $N$ is the average total DIN concentration $(84 \mu \mathrm{M})$ from past surveys of South Bay ponds (A.K. Miles, USGS, pers. comm.), $K_{N}$ is the half-saturation constant ( $=1 \mu \mathrm{M}$; Cloern et al. 1995) that defines phytoplankton growth as a function of DIN concentration, and $k$ is the light attenuation coefficient $\left(=2.97 \mathrm{~m}^{-1}\right)$. Light attenuation was calculated as a linear function of total suspended solid concentration (Cloern 1987) using a mean value of $41 \mathrm{mg} \mathrm{L}^{-1}$ in Pond A18 (City of San Jose 2007b). Daily areal rates of autotrophic respiration $R_{\text {auto }}\left(\mathrm{g} \mathrm{C} \mathrm{m}^{-2} \mathrm{~d}^{-1}\right)$ were calculated as:

$$
R_{\text {auto }}=0.001 \times r_{\text {auto }} \times H \times \frac{[C h l]}{C h l: C}
$$

Finally, the difference between ecosystem respiration and autotrophic respiration is the heterotrophic respiration rate $R_{\text {hetero }}\left(\mathrm{g} \mathrm{C} \mathrm{m}^{-2} \mathrm{~d}^{-1}\right)$ :

$$
R_{\text {hetero }}=E R-R_{\text {auto }} . \quad \text { (Eq. 10) }
$$

We subtracted the percent of GPP represented by $R_{\text {auto }}$ from total GPP to obtain net primary production (NPP). We routed total NPP from the 6 month period of measurement through hypothetical food webs as carbon transferred to pelagic or benthic consumers. Percent of carbon transferred was calculated based on fixed gross growth assimilation efficiencies (GGE $=$ annual production/ingestion) of different consumer groups based on the following published measurements: protistan GGE $=0.28$ and metazoan zooplankton GGE $=0.23$ (Straile 1997); heterotrophic bacteria GGE $=0.25$ (Sobczak et al. 2002); benthic invertebrates GGE = 0.22 (Sprung 1995, Ikeda and Shiga 1999); and planktivorous fish GGE $=0.25$ (Present and Conover 1992).

\section{RESULTS}

\section{Environmental Survey}

Diel variation of $\mathrm{DO}$ concentration $\left(\mathrm{DO}_{\max }-\mathrm{DO}_{\min }\right.$, based on hourly measurements) ranged from 1.78-16.82 $\mathrm{mg} \mathrm{O}_{2} \mathrm{~L}^{-1}$ (average $=6.73 \mathrm{mg} \mathrm{O}_{2} \mathrm{~L}^{-1}$ ). Representative DO curves illustrating the diel variations are presented on Figure 2. Mean daily DO concentration was also highly variable throughout the study period, ranging from $0.5-14.4 \mathrm{mg} \mathrm{L}^{-1}$. Hypoxia events (i.e., DO concentration $<2 \mathrm{mg} \mathrm{O}_{2} \mathrm{~L}^{-1}$; 
Dauer et al. 1992) occurred the third week of May (1.47 $\left.\mathrm{mg} \mathrm{O}_{2} \mathrm{~L}^{-1}\right)$, second week of June $(0.60 \mathrm{mg} \mathrm{O}$ $\left.\mathrm{L}^{-1}\right)$, and mid-to-late July $\left(0.45 \mathrm{mg} \mathrm{O}_{2} \mathrm{~L}^{-1}\right)$ (Figure 3).

Mean daily water temperature in Pond A18 ranged from $17.1-31.7^{\circ} \mathrm{C}$ and exhibited a clear seasonal cycle with maximum values in mid-to-late July (Figure 3). Solar radiation decreased 2-fold from midJuly to late October (Figure 3). Episodes of low mean daily irradiance were observed the third week of May, mid-June, and early and mid October. Pond salinity continuously increased throughout the study period, ranging from 4.6 in early May to 19.4 in late October 2006. Mean daily wind speeds ranged from $0.73-3.30 \mathrm{~m} \mathrm{~s}^{-1}$ with no strong seasonal pattern.

Phytoplankton biomass was very high, with Chl $a$ ranging from $270 \mathrm{mg} \mathrm{m}^{-3}$ in mid-July to $22 \mathrm{mg} \mathrm{m}^{-}$ 3 in late September 2006 (Figure 4). This is contrasted by Chl $a$ values between 3 and $10 \mathrm{mg} \mathrm{m}^{-3}$ in adjacent San Francisco Bay (http://sfbay.wr.usgs.gov/access/wqdata/) during the same period, and 1-8 $\mathrm{mg} \mathrm{m}^{-3}$ in Artesian Slough during September and October. Six species of toxin-producing or harmful phytoplankton were abundant in more than one sample collected in Pond A18: Alexandrium sp., Aureococcus anophagefferens (Hargraves et Sieburth), Chattonella marina (Subrahmanyan), Karenia mikimotoi (Mikyake et Kominami), Anabaenopsis sp., and Anabaena sp. Of these six harmful species, only C. marina and K. mikimoto $i$ were also present outside the pond in Artesian Slough, and both species had substantially lower biomass in the slough than within the pond.

\section{Ecosystem Metabolism Parameters}

Daily rates of gross primary production and ecosystem respiration ranged from 1.06-16.34 $\mathrm{g} \mathrm{O}_{2} \mathrm{~m}^{-2}$ $\mathrm{d}^{-1}$ (May-October average $=8.17 \mathrm{~g} \mathrm{O}_{2} \mathrm{~m}^{-2} \mathrm{~d}^{-1} \equiv 2.79 \mathrm{~g} \mathrm{C} \mathrm{m}^{-2} \mathrm{~d}^{-1}$ ), and 0.01-15.64 $\mathrm{g} \mathrm{O}_{2} \mathrm{~m}^{-2} \mathrm{~d}^{-1}$ (average $=8.25 \mathrm{~g} \mathrm{O}_{2} \mathrm{~m}^{-2} \mathrm{~d}^{-1} \equiv 3.10 \mathrm{~g} \mathrm{C} \mathrm{m}^{-2} \mathrm{~d}^{-1}$ ), respectively (Figure 3). Production and respiration covaried seasonally and were highly correlated $\left(r^{2}=0.82 ; p<0.001\right)$. Estimates of GPP and ER were the same regardless of which reaeration coefficient equation was used (see Appendix A); average standard deviations between equations were 0.13 and $0.16 \mathrm{~g} \mathrm{O}_{2} \mathrm{~m}^{-2} \mathrm{~d}^{-1}$ for GPP and ER respectively. We report metabolic rates using an average diffusion term.

Daily gross primary production appeared to be partly controlled by irradiance (positive linear relationship; $\left.\mathrm{r}^{2}=0.32 ; \mathrm{p}<0.001\right)$. Specifically, sharp drops in GPP and DO concentration in May and June coincided with sharp drops in solar radiation (shaded areas on Figure 3). The decreasing trend of GPP starting in early August occurred synchronously with the late summer decrease in irradiance (Figure 3). DO depletion was also linked to weather events. A severe drop of GPP and DO concentration during the third week of July coincided with a heat wave and abrupt increase in pond temperature above $28^{\circ} \mathrm{C}$ (Figure 3).

Monthly autotrophic and heterotrophic respiration rates ranged from $0.23-0.74 \mathrm{~g} \mathrm{C} \mathrm{m}^{-2} \mathrm{~d}^{-1}$ (mean $=$ $0.46 \mathrm{~g} \mathrm{C} \mathrm{m}^{-2} \mathrm{~d}^{-1}$; s.d. $\left.=0.20\right)$, and from 1.00-4.26 $\mathrm{g} \mathrm{C} \mathrm{m}^{-2} \mathrm{~d}^{-1}\left(\right.$ mean $=2.40 \mathrm{~g} \mathrm{C} \mathrm{m}^{-2} \mathrm{~d}^{-1}$; s.d. $\left.=1.15\right)$, respectively (Figure 4). This implies that $R_{\text {auto }}$ represented between $12.9 \%$ and $18.4 \%$ (mean $=16.4 \%$; s.d. $=1.9 \%)$ of ecosystem respiration and $15.6 \%$ and $20.6 \%$ (mean $=17.4 \%$; s.d. $=2.1 \%)$ of gross primary production. As the pond was not colonized by vascular plants or macroalgae, and no benthic microalgae species, easily re-suspended from the sediments by wind waves, were observed in our water samples, we attribute all $R_{\text {auto }}$ to phytoplankton.

Pond A18 tended to be mostly net heterotrophic (ER > GPP) from May to August and either balanced or net autotrophic (GPP $=$ ER or GPP $>$ ER) in September and October (Figure 4). This seasonal shift is reflected in the trend of increasing DO concentration from August to October, concurrent with decreasing GPP and ER (Figure 3).

Net ecosystem metabolism ranged from -7.27 to $6.22 \mathrm{~g} \mathrm{O}_{2} \mathrm{~m}^{-2} \mathrm{~d}^{-1}$ (三-3.01 to $1.95 \mathrm{~g} \mathrm{C} \mathrm{m}^{-2} \mathrm{~d}^{-1}$ ) with a May-October average of $-0.09 \mathrm{~g} \mathrm{O}_{2} \mathrm{~m}^{-2} \mathrm{~d}^{-1}\left(\equiv-0.31 \mathrm{~g} \mathrm{C} \mathrm{m}^{-2} \mathrm{~d}^{-1}\right.$; Figure 3$)$. Thus, Pond $\mathrm{A} 18$ had a balanced net metabolism over the study period. The total GPP during 6 months of observation in Pond 
A18 was $519 \mathrm{~g} \mathrm{C} \mathrm{m}^{-2}$ ( $\equiv 1521 \mathrm{~g} \mathrm{O}_{2} \mathrm{~m}^{-2}$ ). Over the 330 ha of the pond, this translates to 1713 metric tons of organic carbon produced.

\section{DISCUSSION}

\section{Photosynthesis and Respiration in Pond A18}

Continuous DO measurements in Pond A18 showed that the shallow ponds connected to San Francisco Bay sustain areal gross primary productivity $\left(8.17 \mathrm{~g} \mathrm{O}_{2} \mathrm{~m}^{-2} \mathrm{~d}^{-1}\right)$ roughly double the magnitude of the world's most productive estuaries, such as Chesapeake Bay $\left(4.8 \mathrm{~g} \mathrm{O}_{2} \mathrm{~m}^{-2} \mathrm{~d}^{-1}\right.$; Kemp et al. 1997), and on par with highly productive tidal marsh creeks (Caffrey 2004). In the pond, primary production was realized in $0.7 \mathrm{~m}$ average depth as compared with $7 \mathrm{~m}$ average depth in Chesapeake Bay. Thus, on a volumetric basis $\left(\mathrm{g} \mathrm{O}_{2} \mathrm{~m}^{-3} \mathrm{~d}^{-1}\right)$, Pond $\mathrm{A} 18$ was 17 -fold more productive than Chesapeake Bay. Primary production in Pond A18 was more than 5-fold that in shallow subtidal habitats of South San Francisco Bay, even during the spring bloom (1.55 $\mathrm{g} \mathrm{O}_{2} \mathrm{~m}^{-2} \mathrm{~d}^{-1}$; Caffrey et al. 1998). From a regional perspective, these ponds are important sources of organic matter and energy to fuel production in aquatic food webs. This result is not surprising because the ponds are shallow, highlight and high-nutrient habitats that sustain fast phytoplankton growth and high biomass accumulation. The median phytoplankton growth rate in Pond A18 $\left(0.91 \mathrm{~d}^{-1}\right)$ corresponded to a biomass doubling time of only 18.3 hours, so these ponds function as bioreactors that produce new biomass at rates approaching the maximum capacity of algal cells to divide.

Our study further showed that the high rates of phytoplankton photosynthesis were balanced by equally high rates of community respiration. The synchronous and proportional responses of ER to decreases in GPP suggest that respiration was tightly linked to autochthonous production, so exogenous sources of organic matter contribute little to system metabolism. This finding is similar to that of Caffrey et al. (1998) who showed that photosynthesis in South San Francisco Bay is nearly balanced by benthic and pelagic respiration. This result was expected for Pond A18 where levees prevent organic matter inputs from surrounding wetlands and the volume of estuarine water entering at each tide is negligible compared to the pond's volume. Although there were small seasonal changes, net ecosystem metabolism of Pond A18 was approximately balanced over daily and seasonal time scales (Figures 3, 4). However, this equilibrium is delicately poised because short-term disruptions of photosynthesis led to rapid depletions of oxygen that persisted for days. These hypoxic events were probably linked to weather events: cloudiness from storms in late May and mid June when daily solar radiation dropped abruptly, and a heat wave in July when pond temperatures rose above $28^{\circ} \mathrm{C}$ for 10 consecutive days (Figure 3). The inhibitory effect of high temperature on phytoplankton photosynthesis is well documented, and temperatures above $30^{\circ} \mathrm{C}$ inhibit growth or cause mortality of many temperate phytoplankton species (Butterwick et al. 2005).

\section{Ecological Valuation of Ponds as Feeding Habitats for Birds}

Most of the oxygen consumption in Pond A18 was heterotrophic respiration. This implies high potential production rates of consumers, including invertebrates and fish used as the forage base by millions of shorebirds and waterfowl that flock to San Francisco Bay's ponds (Warnock et al. 2002). The carrying capacity of shallow pond habitats is determined by the pathways and efficiencies of carbon (and energy) transfer from phytoplankton to consumers, which are unknown. However, we can estimate bounds on the carrying capacity measured as potential production rates of forage organisms in Pond A18. Our approach routed algal NPP through a simple pelagic food web leading to production of small planktivorous fish that are harvested by piscivorous birds (e.g., American white pelican, double- 
crested cormorant Phalacrocorax auritus, Caspian tern Hydroprogne caspia, Forster's tern Sterna forsteri), or a benthic food web producing invertebrates harvested by probing shorebirds (western sandpiper Calidris mauri) and diving benthivores (lesser scaup Aythya affinis, greater scaup Aythya marila, ruddy duck Oxyura jamaicensis, eared grebe Podiceps nigricollis). Knowing that autotrophic respiration rate represented on average $17.4 \%$ of GPP, we estimated NPP over the study period to be $82.6 \%$ of GPP, i.e. $428.8 \mathrm{~g} \mathrm{C} \mathrm{m}^{-2}$. We assumed fixed GGEs based on published measurements. Given the complexity of real food webs and high variability of growth efficiencies, we addressed the uncertainty of forage production by comparing efficient algal-based food webs with inefficient detrital food webs in which all algal production is routed through heterotrophic bacteria and then to benthic suspension feeders or protistans before it becomes available to metazoan zooplankton and finally to planktivorous fish. True forage production probably falls between these extremes, so our approach estimated bounds on the potential forage production of different consumer groups. However, bacterial production is small relative to algal production in nutrient-rich water bodies (Berglund et al. 2007), so the true forage production in habitats such as Pond A18 may be close to the upper bounds presented here.

Results showed that potential production of planktivorous fish was between 1.7 and $24.7 \mathrm{~g} \mathrm{C} \mathrm{m}^{-2}$ within a 6 month period, assuming that all primary production is routed through the pelagic food web (Figure 5). This range brackets measures of fish yield as a fraction of primary production in marine ecosystems (Nixon 1988) and the mean fish productivity $\left(10.9 \mathrm{~g} \mathrm{C} \mathrm{m}^{-2} \mathrm{y}^{-1}\right)$ measured in 10 estuaries (Houde and Rutherford 1993). The wet-weight mass of small planktivorous fish, such as year-old Atlantic silverside (Menidia menidia), is about $10 \mathrm{~g}$ (Conover and Ross 1982), corresponding to about $0.5 \mathrm{~g} \mathrm{C}$. Therefore, if all the primary production in Pond A18 is routed through a simple pelagic food web it can support production equivalent to 3-49 small planktivorous fish per square meter, or between 11-163 million fish within the 330-ha pond in this 6 month period. Similar calculations yield estimates of potential invertebrate production in the shorter, more efficient benthic food web of 23.6-94.3 $\mathrm{g} \mathrm{C} \mathrm{m}^{-2}$ in 6 months (Figure 5), a range comparable to measured productivity of estuarine bivalves (see Table 7 in Wilson 2002). Using $0.004 \mathrm{~g} \mathrm{C}$ as the tissue biomass of small bivalves, such as the Asian clam Corbula amurensis (Cole et al. 1992), this calculation implies a pond-scale secondary production equivalent to 19-78 billion clams from May through October. The high algal primary production of Pond A18 implies high rates of forage production for the diverse assemblages of birds that feed in these pond habitats around San Francisco Bay.

Our approach illustrates how easily measured primary production can be transformed into estimates of forage production as a measure of the energetic carrying capacity of estuarine ponds. Carrying capacity is expressed in units (production of fish and clams) that are meaningful for restoration-project managers. Application of this approach across different habitat types can provide project designers a method for comparing the ecological value of those habitats and an objective basis for setting target allocations of newly created habitats by the functions they provide.

\section{Caveats and Hypothesis for Adaptive Restoration Actions}

Our study provides the first measurement of primary production in the former salt ponds of San Francisco Bay, and it reveals a high potential forage production and energy supply to shorebirds and waterfowl. However, measures of production and carbon supply to consumers do not provide the complete information required for ecological valuation of habitats, and we offer three caveats. First, carrying capacity is determined by the quality and packaging of organic carbon produced as well as carbon supply rate. Most of the algal biomass in Pond A18 was in the form of phytoplankton. However, some other shallow ponds around San Francisco Bay are colonized by dense macroalgal beds, i.e., biomass packaged in a form that is not easily accessible to consumers and accumulates to degrade 
water and habitat quality. Success in attaining habitat goals of this restoration project requires new knowledge to identify which pond habitat types promote growth of macroalgae and which promote growth of phytoplankton. Second, there is great variability among phytoplankton species in their accessibility and food value to consumers. Some species in Pond A18 are of high nutritional value such as diatoms (Nitzschia closterium, Cyclotella spp.), cryptophytes, and Mesodinium rubrum. However, other species are toxic (dinoflagellates Alexandrium sp., K. mikimotoi) or impair feeding and metabolism of animals (A. anophagefferens). These taxa often occur in habitats such as Pond A18 with long residence time and high organic content (Gobler et al. 2005). This is in contrast to the waters of San Francisco Bay which have not historically supported harmful algal blooms (Cloern and Dufford 2005). Third, although high algal biomass can support high rates of animal production (Figure 5), it also leads to high system metabolism and susceptibility to episodes of hypoxia when weather events, such as storms and heat waves, trigger declines in photosynthetic oxygen supply (Figure 3). This can lead to hypoxia events in the adjacent sloughs and in the bay.

Shallow estuarine ponds are high-productivity bioreactors that are functionally analogous to aquaculture ponds, except their invertebrate and fish production are harvested by birds instead of humans. From a restoration perspective, these habitats are beneficial because of their food supply function, but detrimental because of their potential to produce toxic or inedible algae and their susceptibility to hypoxic events. Adaptive management of San Francisco Bay's former salt ponds provides an opportunity to determine, empirically, how algal biomass and quality respond to hydraulic manipulations through their control of flushing rate and residence time. We conclude with a testable hypothesis that emerges from our study and can guide adaptive management as the restoration process evolves: algal biomass and food quality in shallow tidal ponds vary with tidal flushing rate; organic content, prevalence of toxic and harmful species, and occurrences of anoxia/hypoxia decrease as flushing rate increases; algal biomass can be manipulated through hydraulic controls to optimize the food supply to consumers and minimize the harmful consequences of excess biomass accumulation.

\section{ACKNOWLEDGMENTS}

We thank A. Keith Miles for sharing nutrient data, Sarah E. Spring for nutrient data management and analyses, and technicians of the U.S. Geological Survey Davis Field Station for nutrient sample collection. Richard Dufford counted and identified phytoplankton, and Jeanne DiLeo designed Figure 1. We are grateful to Kris May and Gregory G. Shellenbarger for helpful comments on an earlier version of this manuscript. We also acknowledge two anonymous reviewers for providing constructive criticism and suggestions that substantially improved this manuscript, and Darold P. Batzer for editorial assistance. Julien Thébault expresses deep appreciation to the U.S. Geological Survey and UMR CNRS 6539 for support of his research stay within the Water Resources Division of the U.S. Geological Survey in Menlo Park, CA. Contribution N ${ }^{\circ} 1079$ of the IUEM, European Institute for Marine Studies (Brest, France).

\section{LITERATURE CITED}

Baker, K. S. and R. Frouin. 1987. Relation between photosynthetically available radiation and total insolation at the ocean surface under clear skies. Limnology and Oceanography 32:1370-1377.

Benson, B. B. and D. Krause. 1984. The concentration and isotopic fractionation of oxygen dissolved in freshwater and seawater in equilibrium with the atmosphere. Limnology and Oceanography 29:620-632. 
Berglund, J., U. Müren, U. Båmstedt, and A. Andersson. 2007. Efficiency of a phytoplankton-based and a bacteria-based food web in a pelagic marine system. Limnology and Oceanography 52:121131.

Butterwick, C., S. I. Heaney, and J. F. Talling. 2005. Diversity in the influence of temperature on the growth rates of freshwater algae, and its ecological relevance. Freshwater Biology 50:291-300.

Caffrey, J. M. 2004. Factors controlling net ecosystem metabolism in U.S. estuaries. Estuaries 27:90101.

Caffrey, J. M., J. E. Cloern, and C. Grenz. 1998. Changes in production and respiration during a spring phytoplankton bloom in San Francisco Bay, California, USA: implications for net ecosystem metabolism. Marine Ecology Progress Series 172:1-12.

City of San Jose. 2007a. Clean bay strategy report for the San Jose/Santa Clara water pollution control plant. Environmental Services Department, San Jose, CA, USA. Available online at http://www.sanjoseca.gov/esd.

City of San Jose. 2007b. 2006 Self-monitoring program report for Pond A18. Environmental Services Department, San Jose, CA, USA. Available online at http://www.sanjoseca.gov/esd.

Clesceri, L. S., A. E. Greenberg, and A. D. Eaton (eds.). 1998. Standard Methods for the Examination of Water and Wastewater, twentieth edition. APHA/AWWA/WEF, Washington, DC, USA.

Cloern, J. E. 1987. Turbidity as a control on phytoplankton biomass and productivity in estuaries. Continental Shelf Research 7:1367-1381.

Cloern, J. E. and R. Dufford. 2005. Phytoplankton community ecology: principles applied in San Francisco Bay. Marine Ecology Progress Series 285:11-28.

Cloern, J. E., C. Grenz, and L. V. Lucas. 1995. An empirical model of the phytoplankton chlorophyll:carbon ratio - the conversion factor between productivity and growth rate. Limnology and Oceanography 40:1313-1321.

Cole, B. E., J. K. Thompson, and J. E. Cloern. 1992. Measurement of filtration rates by infaunal bivalves in a recirculating flume. Marine Biology 113:219-225.

Conomos, T. J. 1979. San Francisco Bay: The Urbanized Estuary. Pacific Division of the American Association for the Advancement of Science, San Francisco, CA, USA.

Conover, D. O. and M. R. Ross. 1982. Patterns in seasonal abundance, growth and biomass of the Atlantic silverside, Menidia menidia, in a New England Estuary. Estuaries 5:275-286.

Cox, B. A. 2003. A review of dissolved oxygen modelling techniques for lowland rivers. The Science of the Total Environment 314-316:303-334.

Cussler, E. L. 1984. Diffusion: Mass Transfer in Fluid Systems. Cambridge University Press, Cambridge, England.

Dauer, D. M., A. J. Rodi, and J. A. Ranasinghe. 1992. Effects of low dissolved oxygen events on the macrobenthos of the lower Chesapeake Bay. Estuaries 15:384-391.

Gobler, C. J., D. J. Lonsdale, and G. L. Boyer. 2005. A review of the causes, effects and potential management of harmful brown tide blooms caused by Aureococcus anophagefferens (Hargraves et Sieburth). Estuaries 28:726-749.

Hartman, B. and D. E. Hammond. 1985. Gas exchange in San Francisco Bay. p. 59-68. In J. E. Cloern and F. H. Nichols (eds.) Temporal Dynamics of an Estuary: San Francisco Bay. Dr W. Junk Publishers, Dordrecht, The Netherlands.

Houde, E. D. and E. S. Rutherford. 1993. Recent trends in estuarine fisheries: predictions of fish production and yield. Estuaries 16:161-176.

Ikeda, T. and N. Shiga. 1999. Production, metabolism and production/biomass (P/B) ratio of Themisto japonica (Crustacea: Amphipoda) in Toyama Bay, southern Japan Sea. Journal of Plankton Research 21:299-308. 
Kemp, W. M., E. M. Smith, M. Marvin-DiPasquale, and W. R. Boynton. 1997. Organic carbon balance and net ecosystem metabolism in Chesapeake Bay. Marine Ecology Progress Series 150:229-248.

Laws, E. A. 1991. Photosynthetic quotients, new production and net community production in the open ocean. Deep-Sea Research 38:143-167.

Liss, P. S. and L. Merlivat. 1986. Air-sea gas exchange rates: introduction and synthesis. p. 113-127. In P. Buat-Menard (ed.) The Role of Air-Sea Exchange in Geochemical Cycling. Reidel Publishing Company, Dordrecht, The Netherlands.

Lopez, C. B., J. E. Cloern, T. S. Schraga, A. J. Little, L. V. Lucas, J. K. Thompson, and J. R. Burau. 2006. Ecological values of shallow-water habitats: implications for the restoration of disturbed ecosystems. Ecosystems 9:422-440.

McKenna, J. E. 2003. Community metabolism during early development of a restored wetland. Wetlands 23:35-50.

Nichols, F. H., J. E. Cloern, S. N. Luoma, and D. H. Peterson. 1986. The modification of an estuary. Science 231:567-573.

Nixon, S. W. 1988. Physical energy inputs and the comparative ecology of lake and marine ecosystems. Limnology and Oceanography 33:1005-1025.

O'Connor, D. J. 1983. Wind effects on gas-liquid transfer coefficients. Journal of Environmental Engineering 109:731-752.

Odum, H. T. 1956. Primary production in flowing waters. Limnology and Oceanography 1:102-117.

Present, T. M. C. and D. O. Conover. 1992. Physiological basis of latitudinal growth differences in Menidia menidia: variation in consumption or efficiency? Functional Ecology 6:23-31.

Ro, K. S. and P. G. Hunt. 2006. A new unified equation for wind-driven surficial oxygen transfer into stationary water bodies. Transactions of the American Society of Agricultural and Biological Engineers 49:1615-1622.

Russell, M. J. and P. A. Montagna. 2007. Spatial and temporal variability and drivers of net ecosystem metabolism in western Gulf of Mexico estuaries. Estuaries and Coasts 30:137-153.

Sobczak, W. V., J. E. Cloern, A. D. Jassby, and A. B. Müller-Solger. 2002. Bioavailability of organic matter in a highly disturbed estuary: the role of detrital and algal resources. Proceedings of the National Academy of Sciences of the United States of America 99:8101-8105.

Sprung, M. 1995. Physiological energetics of the zebra mussel Dreissena polymorpha in lakes II. food uptake and gross growth efficiency. Hydrobiologia 304:133-146.

Straile, D. 1997. Gross growth efficiencies of protozoan and metazoan zooplankton and their dependence on food concentration, predator-prey weight ratio, and taxonomic group. Limnology and Oceanography 42:1375-1385.

Sündermann, J. (ed.). 1986. Landolt-Börnstein: Numerical Data and Functional Relationships in Science and Technology, Group V, Volume 3a. Springer-Verlag, Berlin, Germany.

Takekawa, J. Y., A. K. Miles, D. H. Schoellhamer, N. D. Athearn, M. K. Saiki, W. D. Duffy, S. Kleinschmidt, G. G. Shellenbarger, and C. A. Jannusch. 2006. Trophic structure and avian communities across a salinity gradient in evaporation ponds of the San Francisco Bay estuary. Hydrobiologia 567:307-327.

UNESCO. 1981. Tenth report of the joint panel on oceanographic tables and standards. UNESCO Technical Papers in Marine Science, $n^{\circ} 36$, Paris, France.

Warnock, N., G. W. Page, T. D. Ruhlen, N. Nur, J. Y. Takekawa, and J. T. Hanson. 2002. Management and conservation of San Francisco Bay salt ponds: effects of pond salinity, area, tide, and season on Pacific Flyway waterbirds. Waterbirds 25(Special Publication 2):79-92.

Wilson, J. G. 2002. Productivity, fisheries and aquaculture in temperate estuaries. Estuarine, Coastal and Shelf Science 55:953-967. 
Wool, T. A., R. B. Ambrose, J. L. Martin, and E. A. Comer. 2001. Water quality analysis simulation program (WASP) version 6.0 draft: user's manual. U.S. Environmental Protection Agency, Atlanta, GA, USA. 


\section{APPENDIX A}

Here we detail the methodology used to calculate volumetric reaeration coefficients $k_{a}$. O'Connor (1983) developed a relationship between the transfer coefficient of sparingly soluble gases and wind velocity, based on the liquid film and surface renewal concepts:

$K_{L}=\left(\frac{D_{w}}{v_{w}}\right)^{2 / 3} \times\left(\frac{\rho_{a}}{\rho_{w}}\right)^{1 / 2} \times \frac{\kappa^{1 / 3}}{\Gamma_{0}} \times U^{*} \quad$ (Eq. A1)

where $K_{L}$ is the liquid-phase oxygen mass transfer coefficient $\left(\mathrm{m} \mathrm{d}^{-1}\right), v_{w}$ is the kinematic viscosity of water calculated from Eq. A2-A4 $\left(\mathrm{m}^{2} \mathrm{~s}^{-1}\right), D_{w}$ is the diffusivity of $\mathrm{O}_{2}$ in water calculated from Eq. A5 $\left(\mathrm{m}^{2} \mathrm{~s}^{-1}\right), \rho_{a}$ is the density of air calculated from Eq. A6 $\left(\mathrm{kg} \mathrm{m}^{-3}\right), \rho_{w}$ is the density of water calculated according to IES-80 $\left(\mathrm{kg} \mathrm{m}^{-3}\right.$, UNESCO 1981), $\kappa$ is the dimensionless Von Karman constant $(=0.4), \Gamma_{0}$ is the dimensionless viscous sublayer thickness ( $=6.5$ for most lakes and reservoirs; Wool et al. 2001), and $U^{*}$ is the wind shear velocity calculated from Eq. A7 $\left(\mathrm{m} \mathrm{d}^{-1}\right)$.

The kinematic viscosity of water is the ratio of the dynamic viscosity $\left(\mu_{w}\right.$, in $\left.\mathrm{kg} \mathrm{m}^{-1} \mathrm{~s}^{-1}\right)$ and the density of water and was calculated hourly:

$v_{w}=\frac{\mu_{w}}{\rho_{w}} . \quad($ Eq. A2)

The dynamic viscosity of water was calculated hourly according to Sündermann (1986):

$\mu_{w}=\mu_{p w} \times\left(\begin{array}{l}1+\left(5.185 \times 10^{-5} \times T+1.0675 \times 10^{-4}\right) \times\left(\frac{\rho_{w} \times S}{1806.55}\right)^{1 / 2} \\ +\left(3.3 \times 10^{-5} \times T+2.591 \times 10^{-3}\right) \times\left(\frac{\rho_{w} \times S}{1806.55}\right)\end{array}\right)$

where $\mu_{p w}$ is the dynamic viscocity of pure water $\left(\mathrm{kg} \mathrm{m}^{-1} \mathrm{~s}^{-1}\right), S$ is water salinity, $T$ is water temperature $\left({ }^{\circ} \mathrm{C}\right)$.

The dynamic viscocity of pure water, expressed as a function of water temperature, was calculated hourly according to Sündermann (1986):

$\mu_{p w}=1.002 \times 10^{-3} \times 10^{\left(\frac{1.1709 \times(20-T)-1.827 \times 10^{-3} \times(T-20)^{2}}{T+89.93}\right)}$.

The diffusivity of $\mathrm{O}_{2}$ in water was calculated hourly according to Cussler (1984):

$D_{w}=\frac{k_{B} \times T}{4 \pi \times \mu_{w} \times R_{o}}$

where $k_{B}$ is the Boltzmann's constant $\left(=1.3806503 \times 10^{-23} \mathrm{~m}^{2} \mathrm{~kg} \mathrm{~s}^{-2} \mathrm{~K}^{-1}\right), T$ is water temperature $(\mathrm{K})$, and $R_{o}$ is the radius of the $\mathrm{O}_{2}$ molecule $\left(=1.72 \times 10^{-10} \mathrm{~m}\right.$; Cussler 1984).

The density of air was calculated hourly using the following formula: 
$\rho_{a}=\frac{P_{a t m}-P_{v}}{R_{d} \times T_{a i r}}+\frac{P_{v}}{R_{v} \times T_{\text {air }}}$

where $P_{\text {atm }}$ is the atmospheric pressure $(\mathrm{Pa}), P_{v}$ is the water vapor pressure $(\mathrm{Pa}), R_{d}$ is the gas constant for dry air $\left(=287.05 \mathrm{~J} \mathrm{~kg}^{-1} \mathrm{~K}^{-1}\right), R_{v}$ is the gas constant for water vapor $\left(=461.495 \mathrm{~J} \mathrm{~kg}^{-1} \mathrm{~K}^{-1}\right)$, and $T_{\text {air }}$ is air temperature $(\mathrm{K})$.

Wind shear velocity was calculated hourly using the following equation:

$U^{*}=\sqrt{C_{d}} \times U_{10} \times 86400$

where $C_{d}$ is the dimensionless drag coefficient $(=0.0011)$ and $U_{10}$ is the wind speed at $10 \mathrm{~m}$ height (m $\mathrm{s}^{-1}$ ), calculated according to Eq. A8. Union City wind speed data were normalized to $10 \mathrm{~m}$ assuming the logarithmic wind profile (Ro and Hunt 2006):

$U_{10}=U_{z} \times \frac{\ln \left(\frac{10}{z_{0}}\right)}{\ln \left(\frac{z}{z_{0}}\right)}$

where $z$ is the height of actual wind speed measurement ( $=6.9 \mathrm{~m}$ in Union City), $U_{z}$ is the wind speed measured in Union City $\left(\mathrm{m} \mathrm{s}^{-1}\right)$, and $z_{0}$ is the surface roughness length $\left(=10^{-5} \mathrm{~m}\right.$ for smooth water surface; Ro and Hunt 2006).

Hartman and Hammond (1985) compiled gas exchange rates measured in San Francisco Bay with those for other wind-dominated systems and derived an equation for predicting the gas transfer coefficient in wind-dominated systems:

$K_{L}=34.6 \times R_{v i s c} \times\left(D_{w, 20^{\circ} \mathrm{C}} \times 10^{4}\right)^{1 / 2} \times U_{10}^{3 / 2}$

where $R_{\text {visc }}$ is the ratio of the kinematic viscosity of pure water at $20^{\circ} \mathrm{C}$ to the kinematic viscosity of water at the measured temperature and salinity (calculated using Eq. A2-A4) and $D_{w, 20^{\circ} \mathrm{C}}$ is the diffusivity of $\mathrm{O}_{2}$ at $20^{\circ} \mathrm{C}$ calculated using Eq. A5 $\left(\mathrm{m}^{2} \mathrm{~s}^{-1}\right)$.

Ro and Hunt (2006) recently published a new, unified equation for oxygen mass transfer coefficients based on gas transfer data published during the last $50 \mathrm{yr}$ :

$$
K_{L}=0.24 \times 170.6 \times\left(\frac{D_{w}}{v_{w}}\right)^{1 / 2} \times\left(\frac{\rho_{a}}{\rho_{w}}\right)^{1 / 2} \times U_{10}^{1.81}
$$

We finally calculated volumetric reaeration coefficients $\left(k_{a}, \mathrm{~h}^{-1}\right)$ according to Cox (2003):

$k_{a}=\frac{1}{24} \times \frac{K_{L}}{H} \quad$ (Eq. A11)

where $H$ is the mean depth of the pond $(=0.7 \mathrm{~m})$. 


\section{LIST OF FIGURE CAPTIONS}

Figure 1. Upper panel: map of South San Francisco Bay ringed with ponds, note color variations in ponds due to bacteria and phytoplankton species, San Francisco Bay inset. Lower panel: map of Pond A18 including inlet and outlet water control structures. Satellite images courtesy of NASA (images altered for ease of viewing). Bay area inset and image design courtesy of Jeanne DiLeo (USGS).

Figure 2. Diel cycles of DO concentration in Pond A18 from May 25 to May 27, 2006.

Figure 3. Pond A18 May-October 2006 daily mean DO concentration, pond temperature, photosynthetically active radiation, gross primary production $( \pm 1$ s.d. $)$, ecosystem respiration $( \pm 1$ s.d.), and net ecosystem metabolism ( \pm 1 s.d.). Shaded areas highlight periods of low DO and GPP coincident with extreme high pond temperature or low PAR. Standard deviations are derived from three different equations used for the computation of the reaeration coefficient. Data gaps are due to discarded DO data.

Figure 4. Monthly measurements (May-October 2006) of chlorophyll $a$ concentration, estimates of autotrophic respiration $\left(\mathrm{R}_{\text {auto }}\right)$, heterotrophic respiration $\left(\mathrm{R}_{\text {hetero }}\right)$ and gross primary production (GPP; 7$\mathrm{d}$ mean values centered on Chl $a$ sampling dates) in Pond A18.

Figure 5. Idealized food webs and potential forage production $\left(\mathrm{g} \mathrm{C} \mathrm{m}^{-2}\right)$ in Pond $\mathrm{A} 18$ based on net primary production of $428.8 \mathrm{~g} \mathrm{C} \mathrm{m}^{-2}$ over the 6 month sampling period. Carbon is transferred to pelagic or benthic consumers through algal-based (plain arrows) and bacterial-based (dashed arrows) food webs. Percentages next to arrows are gross growth efficiencies. 


\section{FIGURE 1}

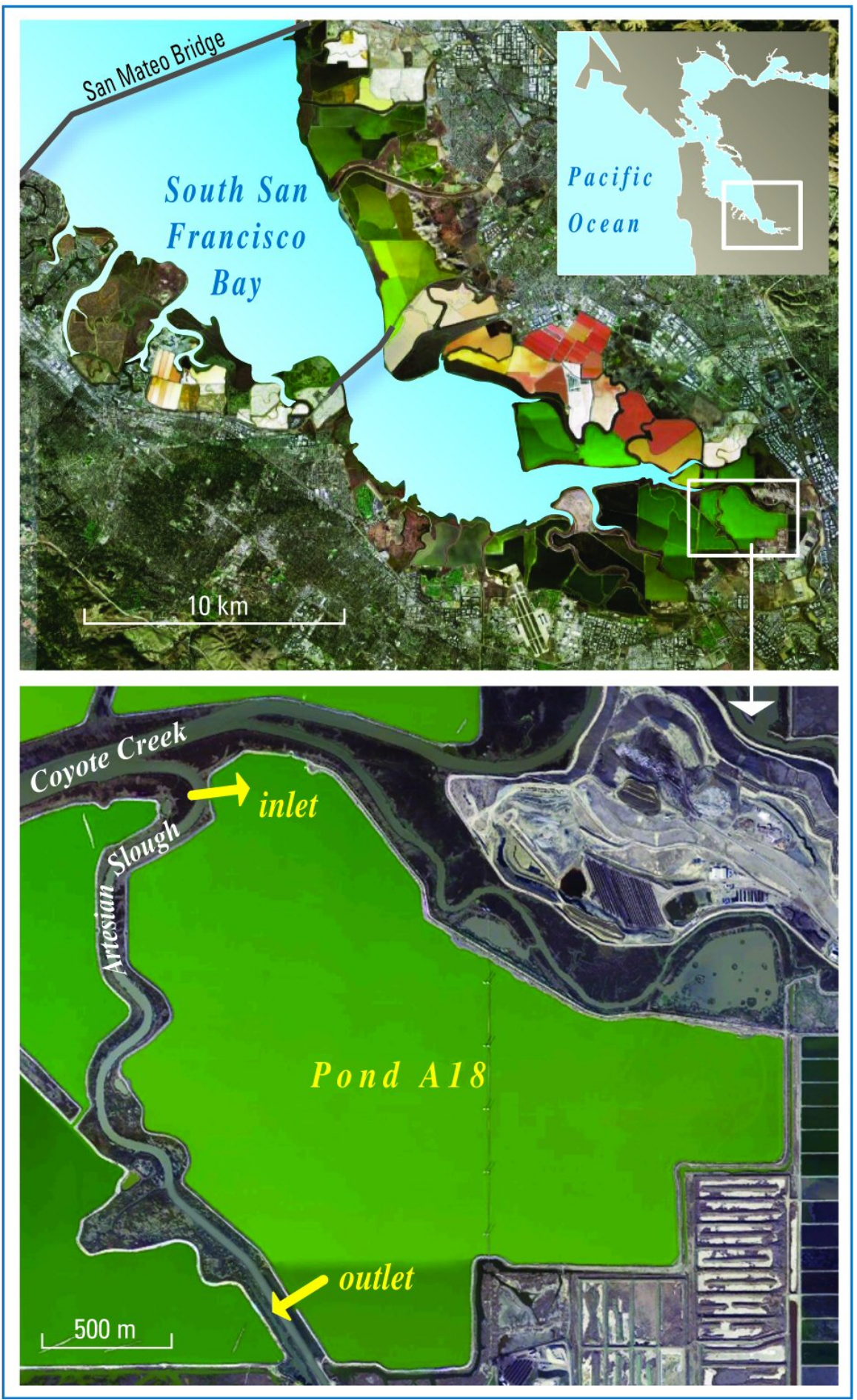




\section{FIGURE 2}

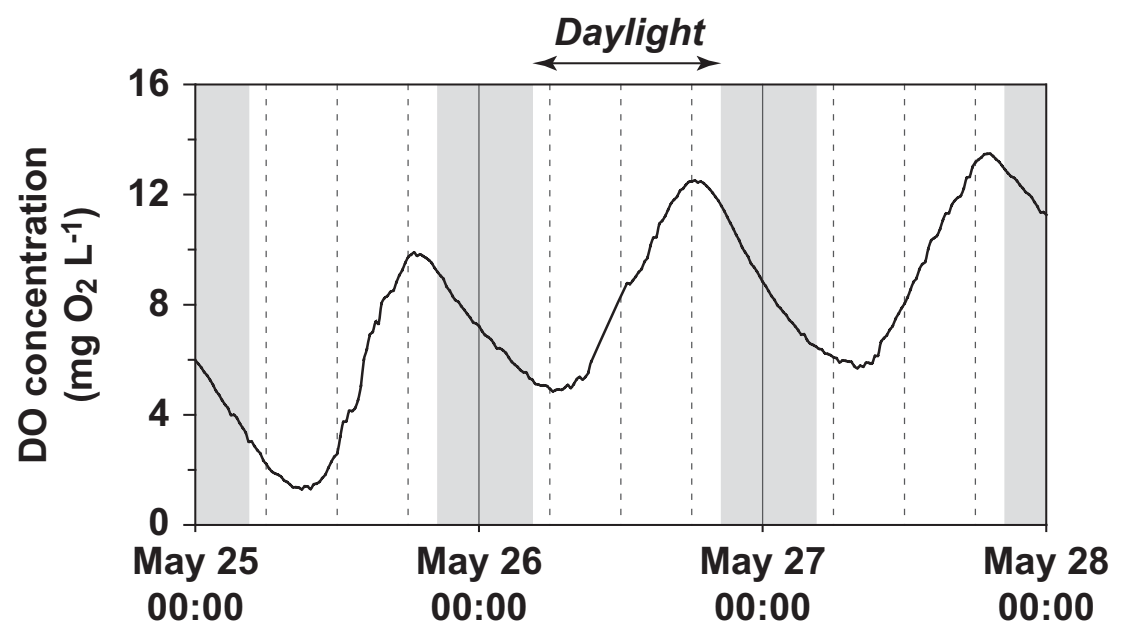




\section{FIGURE 3}
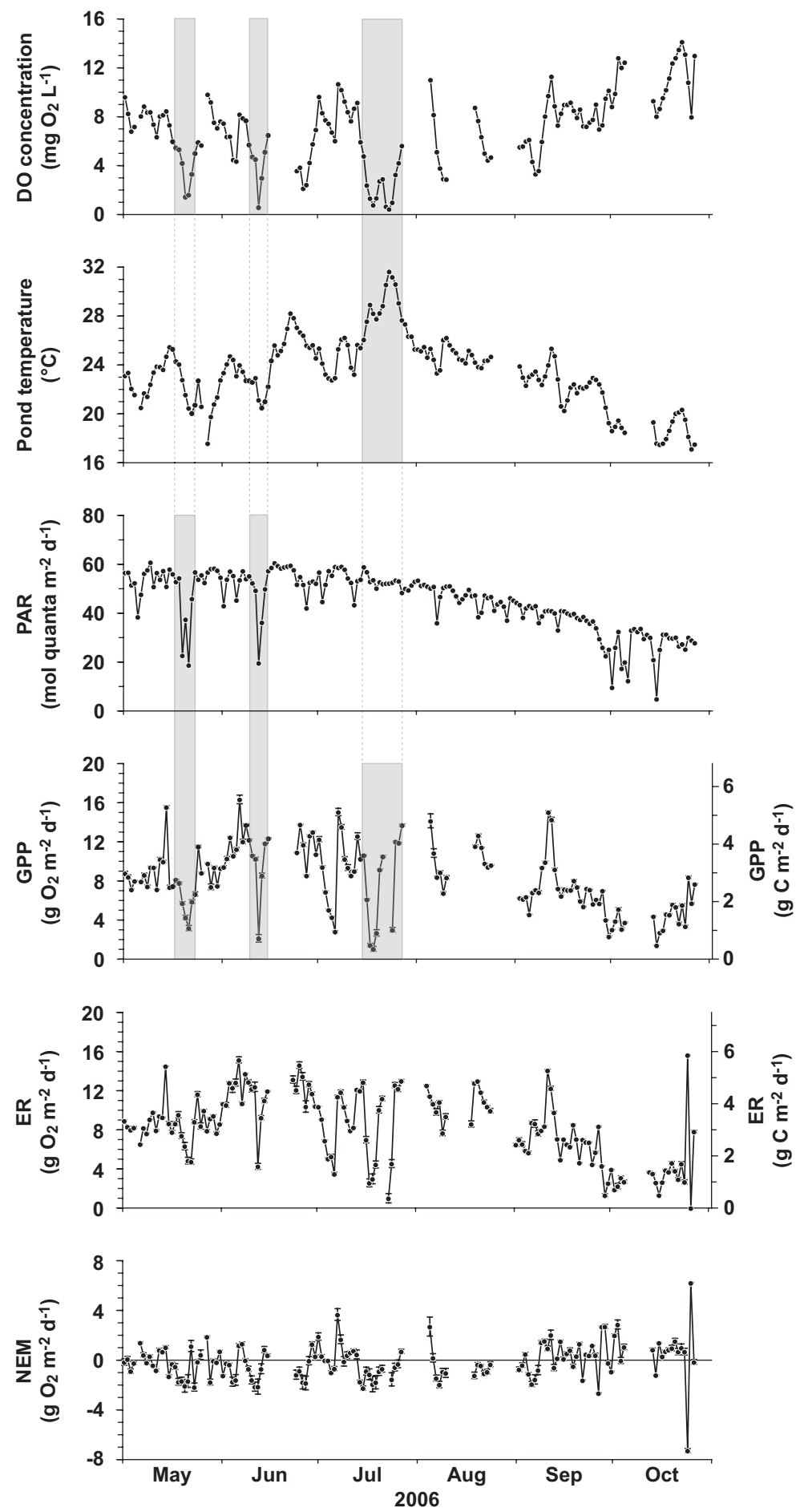


\section{FIGURE 4}

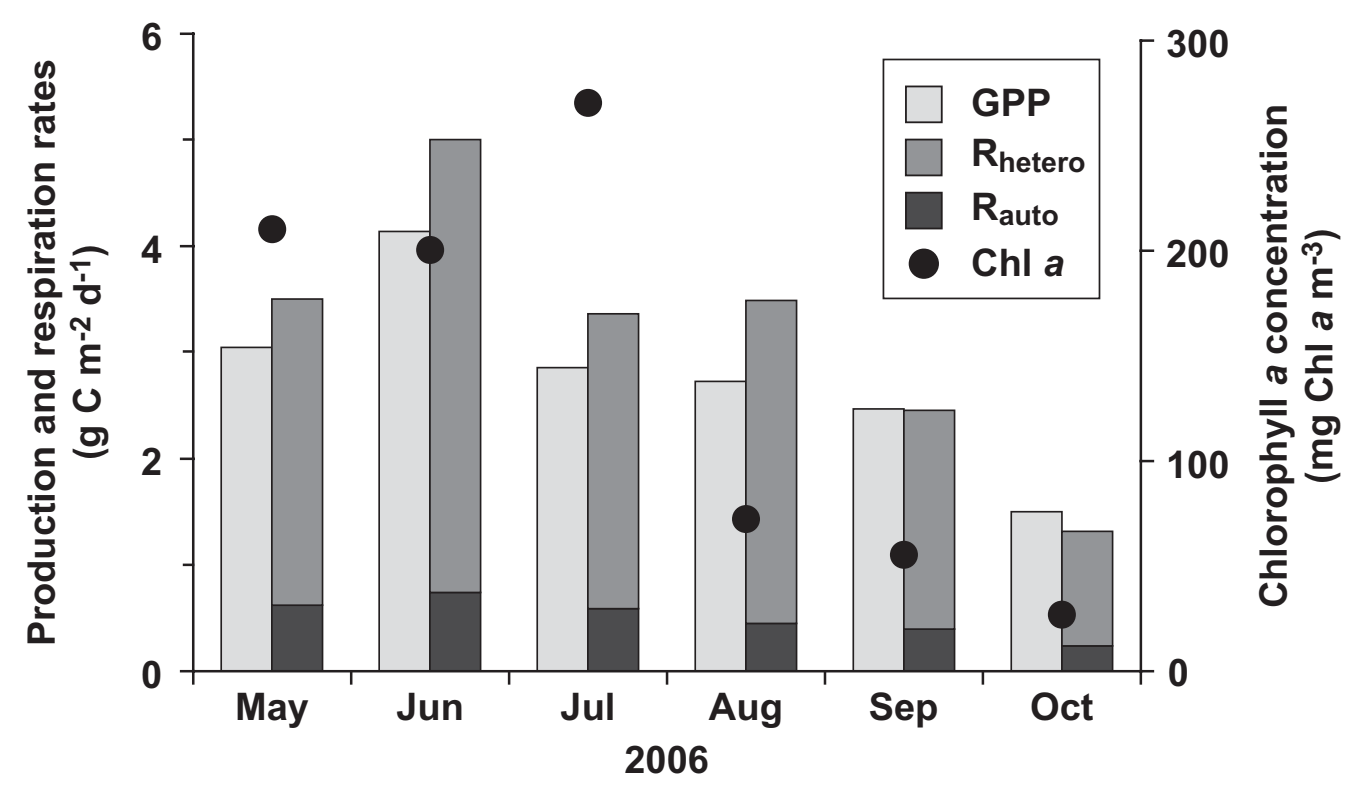




\section{FIGURE 5}

\section{PELAGIC FOOD WEBS}

\section{BENTHIC FOOD WEBS}

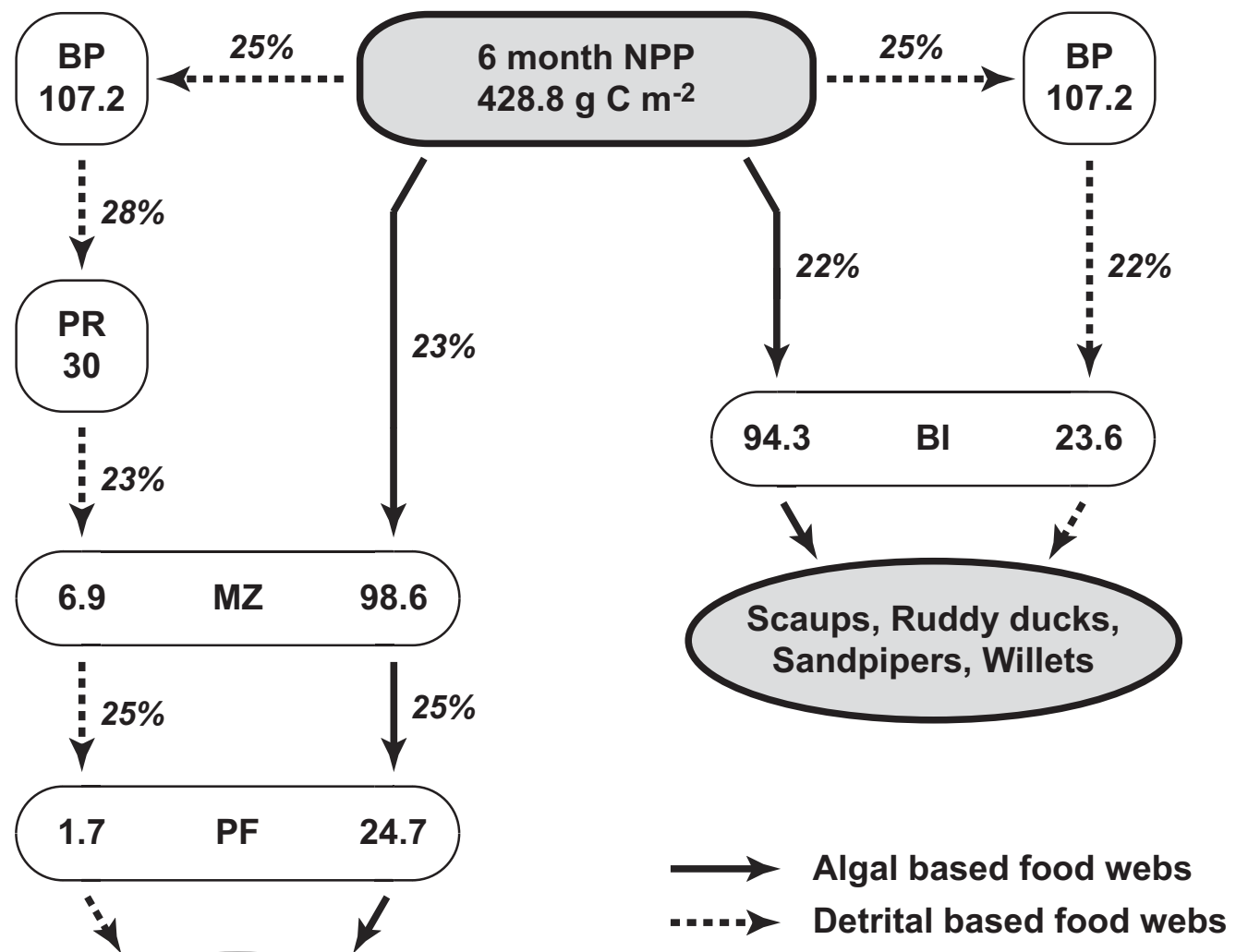

Pelicans, Cormorants

Terns, Herons, Egrets

$\mathrm{BP}=$ bacterial production

PR $=$ protistans (flagellates, ciliates, dinoflagellates)

MZ = mesozooplankton (cladocerans, rotifers, copepods)

$\mathrm{BI}$ = benthic invertebrates (bivalves, polychaetes, amphipods)

$\mathrm{PF}=$ planktivorous fish 